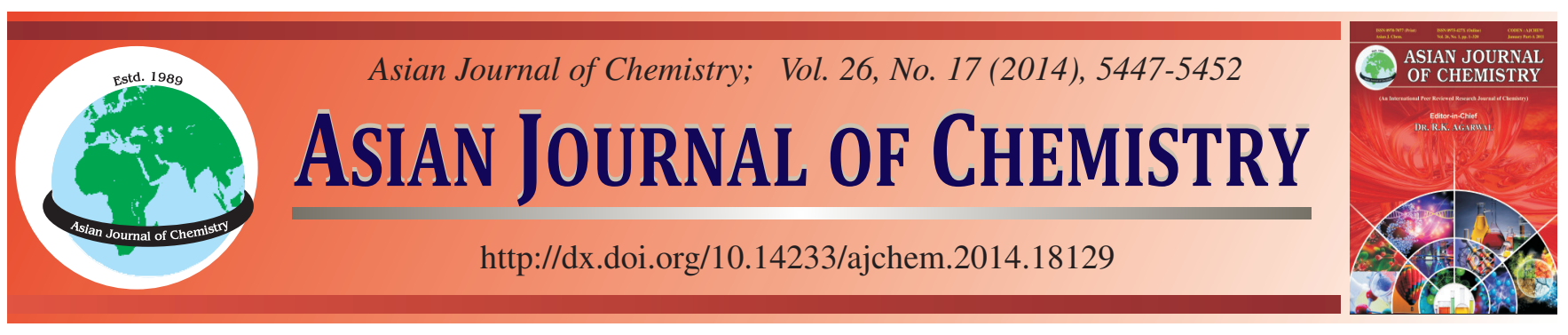

\title{
Preparation, Photoelectricity Property and Photocatalytic Activity of Alkaline-Earth Metals Modified $\mathrm{TiO}_{2}$ Nanoparticles $\dagger$
}

\author{
Zong-Yi Min ${ }^{1,2}$, ShaO-You LiU', ${ }^{3, *}$ Zhong-Bing He ${ }^{1,3}$, Yun-Guo Liu ${ }^{1,2, *}$, \\ Guang-Ming Zeng ${ }^{1,2}$, Xin-Jiang Hu ${ }^{1,2}$, Si-Mian Liu ${ }^{1,2}$ and XIN NIE ${ }^{3}$
}

${ }^{1}$ College of Envirnomental Science and Engineering, Hunan University, Changsha, P.R. China

${ }^{2}$ Key Laboratory of Emviromental Biology and Pollution Control, Ministry of Education, Hunan University, Changsha, P.R. China ${ }^{3}$ Institute of Applied Chemistry, College of Chemistry and Materials Engineering, Kaili University, Kaili, P.R. China

*Corresponding authors: Tel./Fax: +86 855 8558093; E-mail: 1sy651204@163.com; liuyunguo@hnu.edu.cn

\begin{abstract}
To find the properties of the IIA main group elements $\left(\mathrm{Me}_{\mathrm{IIA}}\right)$ modified titanium dioxide $\left(\mathrm{TiO}_{2}\right)$ nanomaterials, $\mathrm{Me}_{\mathrm{IIA}}\left(\mathrm{Me}_{\mathrm{IIA}}=\mathrm{Be}, \mathrm{Mg}, \mathrm{Ca}\right.$, $\mathrm{Sr}, \mathrm{Ba})$ modified $\mathrm{TiO}_{2}\left(\mathrm{Me}_{\mathrm{IIA}}-\mathrm{TiO}_{2}\right)$ nanoparticles were successfully prepared by solid state reaction method. Moreover, the microstructure, surface photovoltaic properties and photocatalytic properties of the materials were characterized. The results showed that, except for Ba element, the other IIA metals doped $\mathrm{TiO}_{2}$ nanomaterials were anatase. $\mathrm{Me}_{\mathrm{IIA}}-\mathrm{TiO}_{2}$ materials' micromorphology was spherical nanoparticles and their size distributions were gradually widened with the increase of ionic radius and mass fraction. In addition, UV-visible spectra were red-shifted and approached about $410 \mathrm{~nm}$. Under the same conditions, it was positive that photocatalytic degradation experience of fenvalerate and photoelectric conversion ability of $\mathrm{Me}_{\mathrm{IIA}}-\mathrm{TiO}_{2}$ nanomaterials, following an order of Ca-TiO $2>\mathrm{Sr}-\mathrm{TiO} \mathrm{O}_{2}>\mathrm{Ba}-\mathrm{TiO}{ }_{2}>\mathrm{Mg}-$ $\mathrm{TiO}_{2}>\mathrm{Be}-\mathrm{TiO}_{2}$. However, its quantum efficiency was in order: $\mathrm{Ca}-\mathrm{TiO}_{2}>\mathrm{Ba}-\mathrm{TiO}_{2}>\mathrm{Mg}-\mathrm{TiO}_{2}>\mathrm{Sr}-\mathrm{TiO}_{2}>\mathrm{Be}-\mathrm{TiO}{ }_{2}>\mathrm{TiO}_{2}$.
\end{abstract}

Keywords: Alkaline-earth metals, $\mathrm{TiO}_{2}$, Solid-state reaction, Photovoltaic properties, Fenvalerate, Photocatalytic degradation.

\section{INTRODUCTION}

Fenvalerate is a moderately toxic pesticide and systemic fungicide, which is irritant to eyes as well as skin and possesses high toxicity to bees, fish and poultry. Therefore, the existence of fenvalerate in environmental water is an emerging threat to public health and ecosystem. Consequently, seeking a novel and effective treatment method is of practical importance for wastewater treatment.

In recent years, heterogeneous photocatalytic technology has attracted increasing attention as it can be widely applied in environmental purification because most organic pollutants are believed to be thoroughly degraded by the photocatalytic generated highly reactive species in water, such as ${ }^{\circ} \mathrm{O}$ and ${ }^{\circ} \mathrm{OH}$, etc. Among various semiconductor materials, $\mathrm{TiO}_{2}$-based photocatalysts have been extensively investigated because of their superior photocatalytic oxidation strength and chemical stability, nontoxicity and low cost. However, it should also be noted that the high charge recombination rate and low quantum efficiency are also major drawback for $\mathrm{TiO}_{2}$ photocatalysis and only about $4 \%$ photogenerated charges could transfer to the surface of materials to participate in the photocatalytic reaction ${ }^{1}$. Furthermore, to date, due to its wide band gap (about $3.2 \mathrm{eV}$ ), $\mathrm{TiO}_{2}$ applied in environmental treatment is almost employing UV light with $\lambda<380 \mathrm{~nm}$, which occupies only about $4 \%$ of the sunlight spectrum. It significantly reduces the quantum efficiency of $\mathrm{TiO}_{2}$ photocatalysis and subsequently limits its application in real environmental remediation by directly utilizing the solar energy. Consequently, to develop $\mathrm{TiO}_{2}$ based photocatalysts with improved visible light utilization and high activity is still highly challengeable. Therefore, the modification of $\mathrm{TiO}_{2}$ has been made to improve the availability of visible light especially sunlight photocatalytic activity of $\mathrm{TiO}_{2}$, such as doping with metal/nonmetal elements, dyesensitizing and conjugating with a low band gap semiconductor material.

To date, the metal-doped $\mathrm{TiO}_{2}$ have been primarily focused on the transition metal and rare earth metal. Generally, the incorporation of multi-charge metal ions into the $\mathrm{TiO}_{2}$ lattice could significantly enhance the photocatalytic activity of $\mathrm{TiO}_{2}$ and the doping of low-valent main group elements such as IA main group element of lithium ion is conductive to the 
separation of electron-hole pairs ${ }^{2}$. In addition, some of the IIA and IIIA main group elements are usually acted as an interstitial or substitutional atom embedding into the $\mathrm{TiO}_{2}$ lattice, leading to the variation of electronic structure of $\mathrm{TiO}_{2}$ and the extension of absorption spectrum to visible-light region and subsequently improving the photocatalytic activity of $\mathrm{TiO}_{2}{ }^{3-7}$. Currently, with surfactants or small organic molecules as the templates or structural directing reagents, the metaldoped $\mathrm{TiO}_{2}$ have been developed extensively using various fabrication methods, including the hydrothermal process, solgel synthesis, solid-state reaction. Among aforementioned synthetic methods, most of the procedures are complicated. Alternatively, the solid-state reaction is more facile and promising for preparation of doped $\mathrm{TiO}_{2}$, which could also be extensively applied in the synthesis of high reactive photocatalysts $^{8-12}$.

Herein, a series of visible-light-driven photocatalysts of $\mathrm{Me}_{\mathrm{IIA}}-\mathrm{TiO}_{2}$ were successfully synthesized via a facile solidstate reaction approach. The photocatalytic degradation of fenvalerate by the $\mathrm{Me}_{\mathrm{IIA}}-\mathrm{TiO}_{2}$ under visible light irradiation was investigated. The main objectives were to investigate the universality of solid-state reaction in the fabrication of nanomaterials and how the doping of the IIA main group elements affects the photoelectrochemical property and photocatalytic performance of these resultant $\mathrm{TiO}_{2}$. In addition, it provides a theoretical and experimental basis for the actual applications of $\mathrm{Me}_{\mathrm{IIA}}-\mathrm{TiO}_{2}$ in the removal of fenvalerate existed in the environment conditions including the river, pond, mulberry orchard and apiary.

\section{EXPERIMENTAL}

Titanium butoxide (TBOT, $98 \%$ ), sodium dodecyl sulfate (SDS), $\mathrm{Be}\left(\mathrm{NO}_{3}\right)_{2} \cdot 4 \mathrm{H}_{2} \mathrm{O}, \mathrm{Mg}\left(\mathrm{NO}_{3}\right)_{2} \cdot 6 \mathrm{H}_{2} \mathrm{O}, \mathrm{Sr}\left(\mathrm{NO}_{3}\right)_{2} \cdot 6 \mathrm{H}_{2} \mathrm{O}$, $\mathrm{Ca}\left(\mathrm{NO}_{3}\right)_{2} \cdot 4 \mathrm{H}_{2} \mathrm{O}, \mathrm{Ba}\left(\mathrm{NO}_{3}\right)_{2} \cdot 4 \mathrm{H}_{2} \mathrm{O}$ and pure $\mathrm{TiO}_{2}$ powder $(99.99$ $\%, \mathrm{~S}_{\mathrm{BET}}=44.9 \mathrm{~m}^{2} / \mathrm{g}$ ) were purchased from Tianjin Damao Chemical Reagent Factory, China. All compounds were used without further treatment. Fenvalerate $\left(30 \%, \mathrm{C}_{25} \mathrm{H}_{22} \mathrm{ClNO}_{3}\right)$ was bought from Anhui Jintai Nongyao Huagong Co., Ltd., China.

General procedure: In a typical process, $\mathrm{Be}\left(\mathrm{NO}_{3}\right)_{2} \cdot 4 \mathrm{H}_{2} \mathrm{O}$, $\mathrm{Mg}\left(\mathrm{NO}_{3}\right)_{2} \cdot 6 \mathrm{H}_{2} \mathrm{O}, \quad \mathrm{Sr}\left(\mathrm{NO}_{3}\right)_{2} \cdot 6 \mathrm{H}_{2} \mathrm{O}, \quad \mathrm{Ca}\left(\mathrm{NO}_{3}\right)_{2} \cdot 4 \mathrm{H}_{2} \mathrm{O}$, $\mathrm{Ba}\left(\mathrm{NO}_{3}\right)_{2} \cdot 4 \mathrm{H}_{2} \mathrm{O}$ and SDS were firstly mixed and ground by a mortar for $10 \mathrm{~min}$. Then obtained powder was mixed with titanium butoxide (TBOT) with a molar ratio of $\mathrm{n}\left(\mathrm{Me}_{\mathrm{IIA}}\right)$ : $\mathrm{n}($ TBOT $)=1: 9$ and SDS is $10 \mathrm{wt} \%$ for the total weight of TBOT and alkaline-earth metal nitrates and ground for $15 \mathrm{~min}$. The resulting viscous mixture was transferred into a beaker, followed by aging for $6 \mathrm{~h}$, the white viscous mixtures were heated at $140{ }^{\circ} \mathrm{C}$ for $1.5 \mathrm{~h}$ in an oven. Cooling to room temperature, the obtained solid specimen were ground and washed with distilled water thoroughly and dried at $105^{\circ} \mathrm{C}$. To remove the SDS surfactant, the as-synthesized samples were calcined at $500{ }^{\circ} \mathrm{C}$ in a muffle furnace for $4 \mathrm{~h}$ with a heated temperature rate of $1{ }^{\circ} \mathrm{C} / \mathrm{min}$ to obtain the photocatalysts of $\mathrm{Me}_{\mathrm{IIA}}-\mathrm{TiO}_{2}$ materials.

The X-ray diffraction (XRD) were determined by Xpert Pro diffractometer with $\mathrm{CuK}_{\alpha}$ radiation $(\lambda=0.15406 \mathrm{~nm})$ at a scanning speed of $0.02 \% \mathrm{~min}$. The scanning electron microscopy
(SEM) and energy dispersion spectroscopy (EDS) were carried out on a JSM- 6490LV electron microscopy. Inductively coupled plasma emission spectrometer was determined on ICP2060T. Nitrogen adsorption and desorption isotherms, as well as pore diameter distribution were recorded by nitrogen adsorption apparatus (Micromeritics ASAP 2020 system). The Fourier transforms infrared spectroscopy (FTIR) spectra were investigated with a Spectrum 65 spectrometer. UV-VIS diffuse-reflectance spectra were recorded on a Shimadzu UV-2550PC. The surface photovoltaic properties were performed on surface photovoltage spectrum (SPS) apparatus assembled by micro/nanomaterials testing center of Hunan University. The surface photovoltage cell with a sandwich configuration (ITO/Sample/ ITO) was shown in Fig. 1. All tests were executed out in the indoor environment and the data were obtained without any processing.

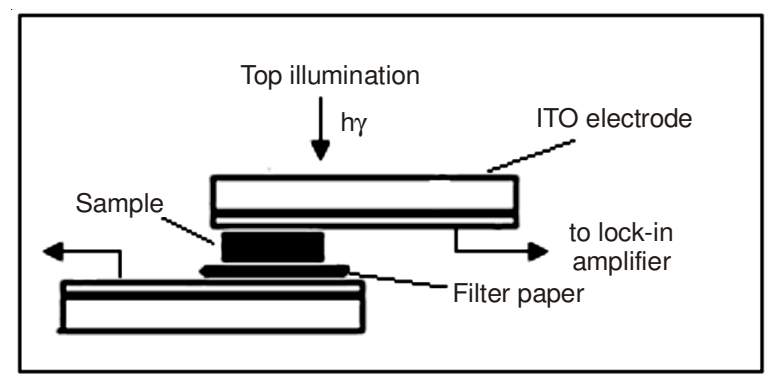

Fig. 1. Chart of surface photovoltage cell configuration

Photocatalytic degradation of fenvalerate by the $\mathrm{Me}_{\mathrm{IIA}}{ }^{-}$ $\mathrm{TiO}_{2}$ was performed in a $50 \mathrm{~mL}$ photochemical reactor XPAVII (Nanjing Xujiang Elechtromechanical Factory, China). A $300 \mathrm{~W}$ metal halogen lamp assisted with Toshiba B-47 optical filter $(\lambda>410 \mathrm{~nm}$, transmittance $>90 \%)$ was used as visible light source. The reaction solution was kept at about $20{ }^{\circ} \mathrm{C}$ as well as $\mathrm{pH}$ of 6.8 and stirred with a magnetic stirrer by $700 \mathrm{r} /$ min. Prior to illumination, a suspension of $20 \mathrm{~mL}$ fenvalerate $\left(\mathrm{C}_{\mathrm{o}}=50 \mathrm{mg} / \mathrm{L}\right)$ with $20 \mathrm{mg}$ photocatalyst was stirred in the dark for $1 \mathrm{~h}$ to achieve the adsorption-desorption equilibrium. A $5 \mathrm{~mL}$ solution was taken at a given time interval and centrifuged for $10 \mathrm{~min}$. The concentration of fenvalerate was determined by UV-VIS spectrophotometer at a wavelength of 216 $\mathrm{nm}$. After detection, the detection solution was taken back into the quartz tube to use next. The photocatalytic degradation efficiency was calculated according to the eqn. 1 (degradation efficiency $=\mathrm{C} / \mathrm{C}_{0}(1)$, where $\mathrm{C}$ presented the content of residual pollutant and $\mathrm{C}_{0}$ was its original content).

\section{RESULTS AND DISCUSSION}

XRD analysis: The XRD patterns of all samples are displayed in Fig. 2. All samples exhibit high intensities characteristic diffraction peaks of anatase $\mathrm{TiO}_{2}$ and no alkali metal oxide or any other phases appeared, suggesting anatase is the main phase in these samples ${ }^{13}$. Compared with pure $\mathrm{TiO}_{2}$, the characteristic diffraction peaks of $\mathrm{Me}_{\mathrm{IIA}}-\mathrm{TiO}_{2}$ exhibits a slight change and an increase in the full width at half-maximum, implying the variation of the lattice parameters and distance of crystal planes. Table- 1 summarizes the lattice parameters $(\mathrm{a}=\mathrm{b}, \mathrm{c})$ and crystallite sizes $(\mathrm{d})$, which were calculated by 
TABLE-1

DATA OF CRYSTALLITE SIZE AND UNIT CELL PARAMETER FROM $\mathrm{Me}_{\mathrm{IIA}}-\mathrm{TiO}_{2}$ POWDER MATERIALS

\begin{tabular}{|c|c|c|c|c|c|c|c|c|}
\hline \multirow{2}{*}{ Sample } & \multicolumn{3}{|c|}{ Unit cell parameter } & \multirow{2}{*}{$\begin{array}{l}\mathrm{C} \\
\text { (a) }\end{array}$} & \multirow{2}{*}{$\begin{array}{c}\text { Crystal size } \\
d_{(101)}(\mathrm{nm})\end{array}$} & \multirow{2}{*}{$\begin{array}{l}\text { Element } \\
\text { name }\end{array}$} & \multirow{2}{*}{$\begin{array}{c}\text { Electro- } \\
\text { negativity }\end{array}$} & \multirow{2}{*}{$\begin{array}{l}\mathrm{Me} \\
(\%)\end{array}$} \\
\hline & $\mathrm{a}(\mathrm{nm})$ & $\mathrm{c}(\mathrm{nm})$ & $\mathrm{V}\left(\mathrm{nm}^{3}\right)$ & & & & & \\
\hline $\mathrm{Be}-\mathrm{TiO}_{2}$ & 0.3778 & 0.9492 & 0.13548 & 2.512 & 12.55 & $\mathrm{Be}$ & 1.5 & 1.02 \\
\hline $\mathrm{Mg}-\mathrm{TiO}_{2}$ & 0.3787 & 0.9342 & 0.13527 & 2.467 & 11.33 & $\mathrm{Mg}$ & 1.2 & 3.08 \\
\hline $\mathrm{Ca}-\mathrm{TiO}_{2}$ & 0.3790 & 0.9593 & 0.13779 & 2.531 & 14.05 & $\mathrm{Ca}$ & 1.0 & 5.05 \\
\hline $\mathrm{Sr}-\mathrm{TiO}_{2}$ & 0.3792 & 0.9438 & 0.13571 & 2.488 & 10.04 & $\mathrm{Sr}$ & 1.0 & 10.27 \\
\hline $\mathrm{Ba}-\mathrm{TiO}_{2}$ & 0.3780 & 0.9449 & 0.13501 & 2.500 & 14.64 & $\mathrm{Ba}$ & 0.9 & 15.12 \\
\hline Pure- $\mathrm{TiO}_{2}$ & 0.3775 & 0.9519 & 0.13565 & 2.521 & 23.40 & $\mathrm{Ti}$ & 1.5 & - \\
\hline
\end{tabular}

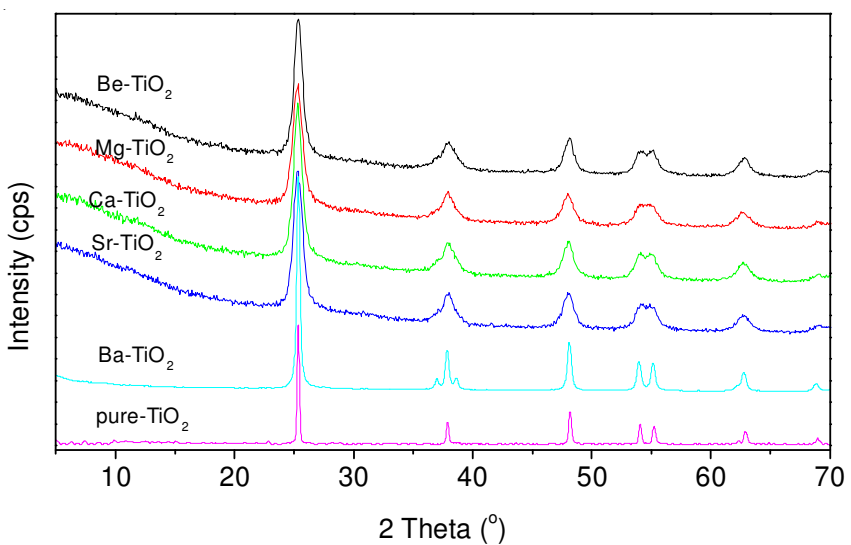

Fig. 2. XRD patterns of the $\mathrm{Me}_{\mathrm{IIA}}-\mathrm{TiO}_{2}$ samples

Bragg's and Scherrer's equation, respectively. It could be seen that the average crystallite size of pure $\mathrm{TiO}_{2}$ is $23.4 \mathrm{~nm}$, while the doping with $\mathrm{Me}_{\text {IIA }}$ results in a decrease in the crystallite size to $10-15 \mathrm{~nm}$, suggesting that doping would hinder the growth of the $\mathrm{TiO}_{2}$ particles and reduce its crystallinity. An increase in the atomic number of doping element led to the first increase and then decrease in the a-axis parameter of $\mathrm{Me}_{\mathrm{IIA}}{ }^{-}$ $\mathrm{TiO}_{2}$, attributing to the difference of alkali metal atomic radius affects the unit cell volume of doped $\mathrm{TiO}_{2}$. The ionic radius of alkali metal follows the order of $\mathrm{Be}^{2+}(31 \mathrm{pm})<\mathrm{Mg}^{2+}(65 \mathrm{pm})$ $<\mathrm{Ca}^{2+}(99 \mathrm{pm})<\mathrm{Sr}^{2+}(113 \mathrm{pm})<\mathrm{Ba}^{2+}(135 \mathrm{pm})^{14}$ and the ionic radius of $\mathrm{Ti}^{4+}$ is $68 \mathrm{pm}$, demonstrating that the ionic radius of $\mathrm{Be}^{2+}$ is lesser than $\mathrm{Ti}^{4+}$. Furthermore, the $\mathrm{Be}-\mathrm{O}$ bond is weak covalent bond, which is different from the ionic bond of Ti-O bond. Consequently, the $\mathrm{Be}^{2+}$ is rarely incorporated into the lattice of $\mathrm{TiO}_{2}$ crystal structure and the content of $\mathrm{Be}$ is only about $1.02 \%$, which is the lowest among all $\mathrm{Me}_{\text {IIA }}$ elements. If considered from the ionic radius, only $\mathrm{Mg}^{2+}$ could be easily incorporated into the structure of $\mathrm{TiO}_{2}$ by isomorphous substitution among all alkali metals. The exchange capacity of different valent elements primarily depends on the balance of positive and negative charges, followed by ionic radius ${ }^{15}$. The imbalance of charges or difference of volume originated from the substitution of $\mathrm{Ti}^{4+}$ or $\mathrm{Ti}^{3+}$ by $\mathrm{Ca}^{2+}$ or $\mathrm{Sr}^{2+}$ could be compensated by the substitutional atom, resulting in the swelled unit cell volume of $\mathrm{Ca}-\mathrm{TiO}_{2}$ and $\mathrm{Sr}-\mathrm{TiO}_{2}$. The migration rate of $\mathrm{Ca}^{2+}$ is faster than $\mathrm{Sr}^{2+}$ as its smaller atomic mass, thus swelling the unit cell volume of $\mathrm{Ca}-\mathrm{TiO}_{2}$. Moreover, the lattice defects in the crystal can also affect the geometric structure of ligands, which could lead to the deviation of $\mathrm{Ti}$ and $\mathrm{O}$ from the equilibrium position, the rearrangement of crystal structure, the change of the lattice parameters and the distance of crystal planes. As a consequence, it distorts the integrity and ordering of the lattice, implying that the doped materials might possess different physical and chemical properties.

SEM-EDS analysis: Fig. 3 demonstrates the SEM images and EDS graphs (Fig. 3) of $\mathrm{Me}_{\mathrm{IIA}}-\mathrm{TiO}_{2}$ prepared at the same conditions. The content of the doped element is listed in Table1. It should be noted that the content of Be was measured by inductively coupled plasma emission spectrometer due to the EDS failed to detect the very little Be. It can be seen that all samples indicate the formation of the spherical particle and the particulate size range of $\mathrm{Be}-\mathrm{TiO}_{2}, \mathrm{Mg}-\mathrm{TiO}_{2}, \mathrm{Ca}-\mathrm{TiO}_{2}$, Sr- $\mathrm{TiO}_{2}$ and $\mathrm{Ba}_{-}-\mathrm{TiO}_{2}$ is 6.7-12, 7.0-14, 7.0-24, 7.0-28 and 7.0$42 \mathrm{~nm}$, respectively, implying an increase in the atomic number of doped element is beneficial to the growth of doped $\mathrm{TiO}_{2}$ particles and results in an increase of the particle size distribution. Simultaneously, the element contents of $\mathrm{Be}, \mathrm{Mg}$, $\mathrm{Ca}$, Sr and $\mathrm{Ba}$ are 1.02, 3.08, 5.05, 10.27 and 15.12, respectively, which also shows a conspicuous monotonic increase with the increase of the ionic radius and decrease of charge density of doped element, confirming the $\mathrm{Me}_{\mathrm{IIA}}$ are successfully doped in $\mathrm{TiO}_{2}$ lattice ${ }^{10}$.

$\mathbf{N}_{2}$ Adsorptio-desorption analysis: The BET surface areas and other structure parameters of $\mathrm{Me}_{\mathrm{IIA}}-\mathrm{TiO}_{2}$ are summarized in Table-2. As shown, the BET surface areas of $\mathrm{TiO}_{2}$ doped with $\mathrm{Me}_{\text {IIA }}$ increase with a decrease in charge density and increase in charge size ratio of ions, except for the samples of $\mathrm{Ba}-\mathrm{TiO}_{2}$. It might be ascribed to that the charge density of doped ions has an important influence on the BET surface areas of $\mathrm{TiO}_{2}$. The pore diameter and pore volume created by stacking crystal grains are different owing to the difference of particulate aggregation extent.

\begin{tabular}{|c|c|c|c|c|}
\hline \multicolumn{5}{|c|}{$\begin{array}{c}\text { TABLE-2 } \\
\text { STRUCTURE PARAMETERS OF } \mathrm{Me}_{\mathrm{IIA}}-\mathrm{TiO}_{2}\end{array}$} \\
\hline Sample & $\begin{array}{l}\text { BET surface } \\
\text { area }\left(\mathrm{m}^{2} / \mathrm{g}\right)\end{array}$ & $\begin{array}{l}\text { Average pore } \\
\text { diameter }(\mathrm{nm})\end{array}$ & $\begin{array}{l}\text { Pore volume } \\
\qquad\left(\mathrm{cm}^{3} / \mathrm{g}\right)\end{array}$ & $\begin{array}{l}\text { Charge } \\
\text { size ratio }\end{array}$ \\
\hline $\mathrm{Be}-\mathrm{TiO}_{2}$ & 62.65 & 4.95 & 0.197 & 0.0645 \\
\hline $\mathrm{Mg}-\mathrm{TiO}_{2}$ & 73.04 & 10.49 & 0.173 & 0.0308 \\
\hline $\mathrm{Ca}-\mathrm{TiO}_{2}$ & 83.82 & 9.12 & 0.159 & 0.0202 \\
\hline $\mathrm{Sr}-\mathrm{TiO}_{2}$ & 102.12 & 8.78 & 0.259 & 0.0177 \\
\hline $\mathrm{Ba}-\mathrm{TiO}_{2}$ & 72.36 & 5.67 & 0.216 & 0.0148 \\
\hline $\mathrm{TiO}_{2}$ & 44.9 & - & - & - \\
\hline
\end{tabular}

UV/visible diffuse-reflectance spectra: According to previous research, hetero atoms enter into the $\mathrm{TiO}_{2}$ structure could lead to the red shift of the absorption edge ${ }^{13}$, the UV/ visible diffuse-reflectance spectra of the samples are shown in Fig. 4. Compared with pure $\mathrm{TiO}_{2}$, the absorption edge of $\mathrm{Me}_{\mathrm{IIA}}-\mathrm{TiO}_{2}$ exhibited a remarkable red-shift and the UV absorption intensity developed the order of $\mathrm{Ca}-\mathrm{TiO}_{2}>\mathrm{Sr}-\mathrm{TiO}_{2}$ 

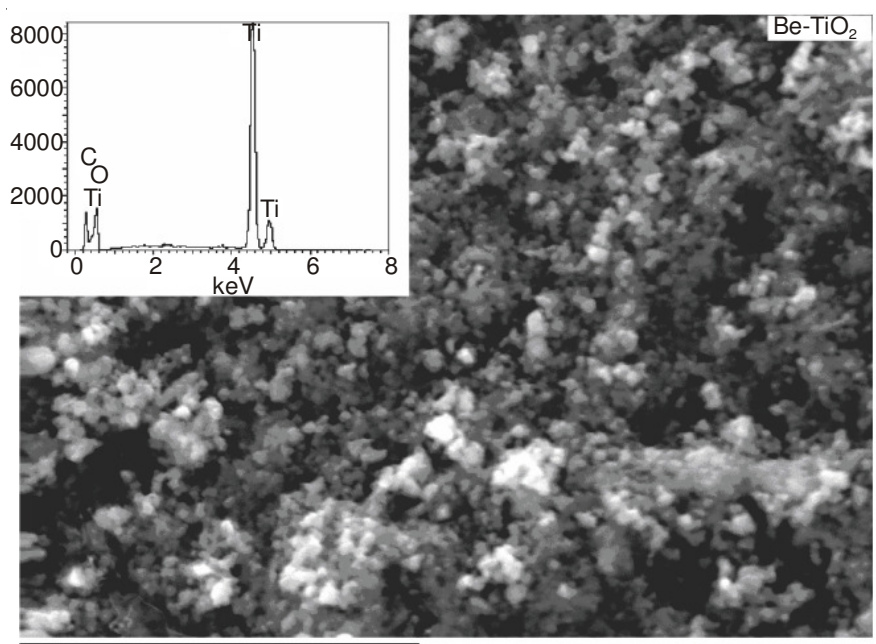

$200 \mathrm{~nm}$
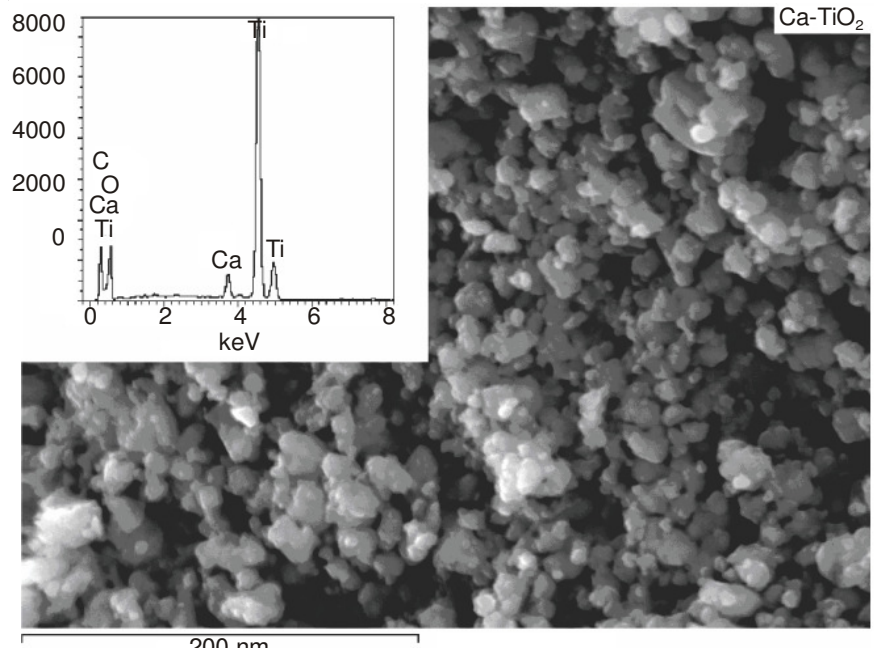

$200 \mathrm{~nm}$

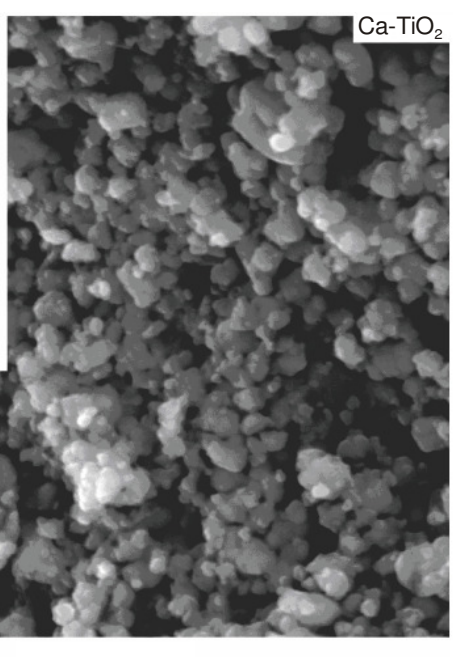

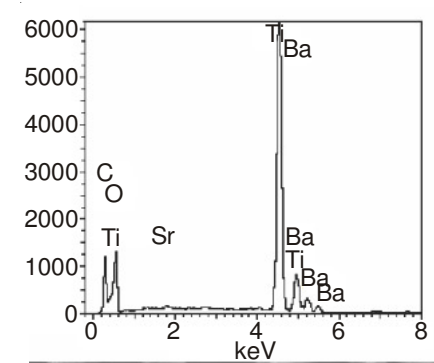
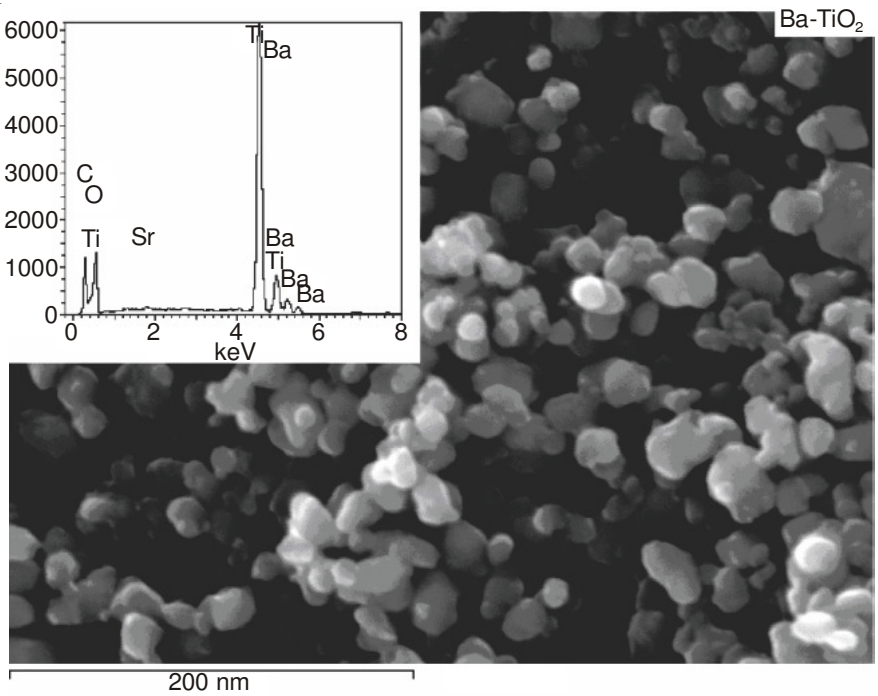

Fig. 3. SEM images and EDS graphs (insert section) of $\mathrm{Me}_{\mathrm{IIA}}-\mathrm{TiO}_{2}$ nanomaterials

$>\mathrm{Ba}-\mathrm{TiO}_{2}>\mathrm{Mg}-\mathrm{TiO}_{2}>\mathrm{TiO}_{2}>\mathrm{Be}-\mathrm{TiO}_{2}$, indicating that $\mathrm{Me}_{\mathrm{IIA}}$ were successfully embedded into the structure or interstitial positions of $\mathrm{TiO}_{2}$ lattice. The corresponding band gap was extrapolated as 2.98, 3.09, 3.13, 2.91 and $2.95 \mathrm{eV}$, inferring the formation of impurity power level in the band gap of $\mathrm{TiO}_{2}$ and subsequently extending the spectral response of the $\mathrm{TiO}_{2}$
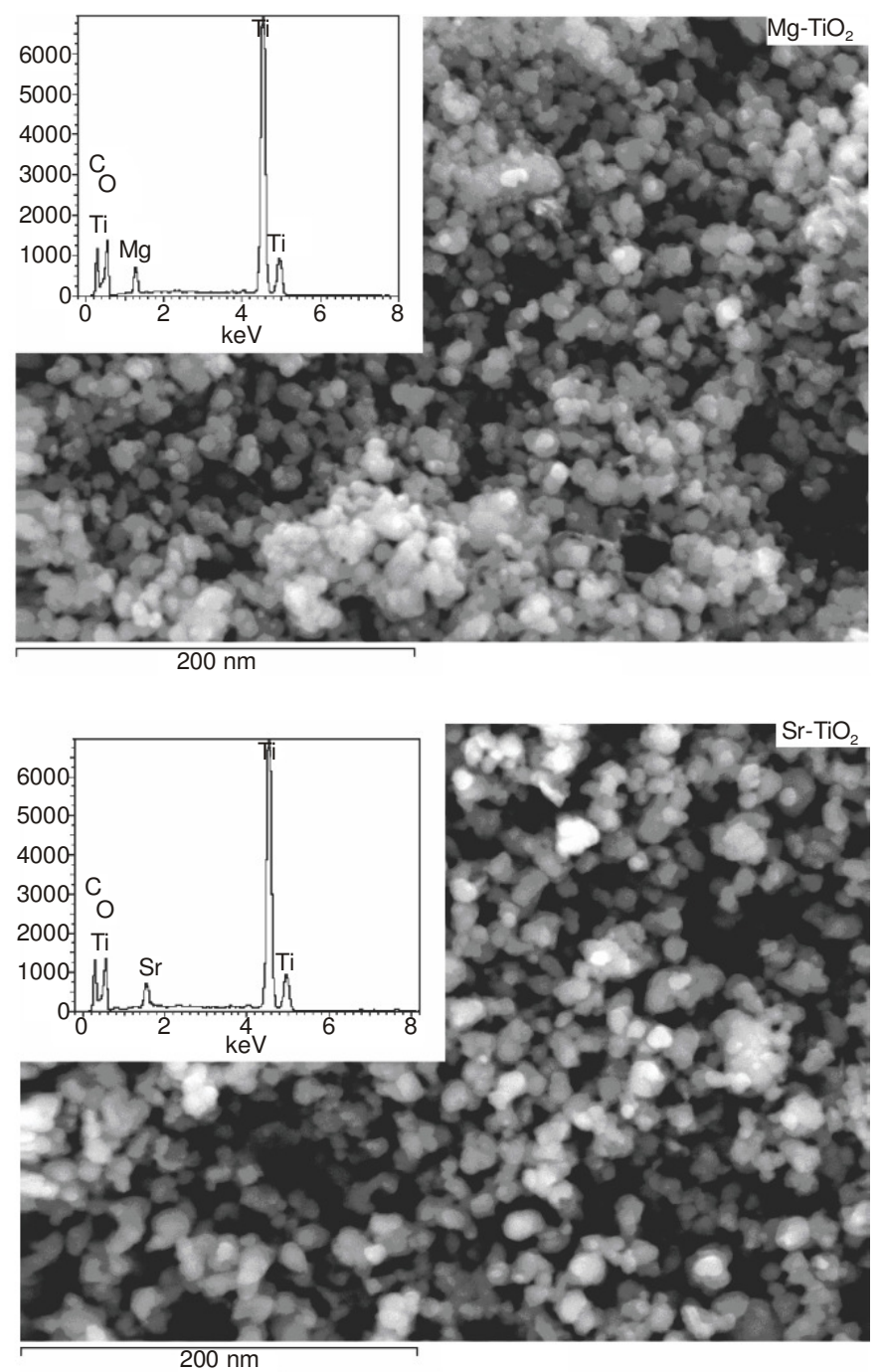

to the visible light region. It is worth noting that the incorporation of alkali metal ions reduces the charge density of $\mathrm{TiO}_{2}$ due to the charge density of alkali metal ions are lower than $\mathrm{TiO}_{2}$, enhancing the atomic orbital expansibility of the energy level and, consequently, improving the delocalization of electrons. Moreover, due to the crystallinity of $\mathrm{Me}_{\mathrm{IIA}}-\mathrm{TiO}_{2}$ is 


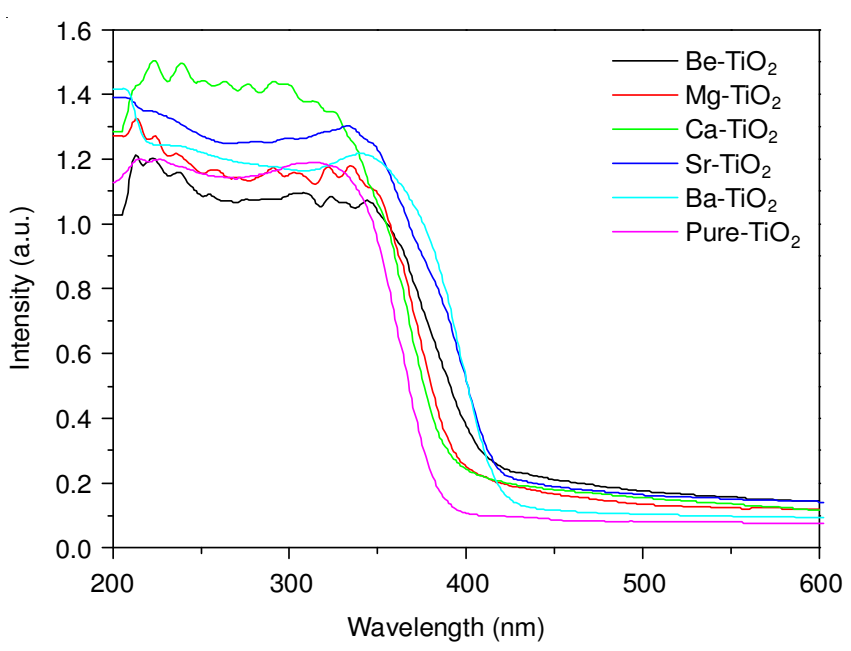

Fig. 4. UV-visible diffuse reflectance spectra of the samples

lower than pure $\mathrm{TiO}_{2}$, the deviation of the amorphous state from perfect crystal lattice leads to the appearance of extended state and delocalized state of energy level.

FT-IR spectra: The FT-IR spectra were used to further verify the organic functional groups of the prepared photocatalysts. Compared with pure $\mathrm{TiO}_{2}$, the peaks at 965, 1085, 1093, 1125, 1078, 1089 and $1093 \mathrm{~cm}^{-1}$ shown in Fig. 5 can be attributed to the bending vibration of Ti-O-Me $\mathrm{MIA}_{\text {IIA }}$ bond in $\mathrm{Me}_{\text {IIA }}$ $\left(\mathrm{Me}_{\mathrm{IIA}}=\mathrm{Be}^{2+}, \mathrm{Mg}^{2+}, \mathrm{Ca}^{2+}, \mathrm{Sr}^{2+}\right.$ and $\left.\mathrm{Ba}^{2+}\right)-\mathrm{TiO}_{2}{ }^{16,17}$. The peak intensity of $\mathrm{O}-\mathrm{H}$ bond for $\mathrm{Ba}-\mathrm{TiO}_{2}$ is the strongest among all $\mathrm{Me}_{\text {IIA }}-\mathrm{TiO}_{2}$, suggesting it has the highest surface polarity. The above results further verify that $\mathrm{Me}_{\text {IIA }}$ is successfully incorporated into the $\mathrm{TiO}_{2}$ lattice.

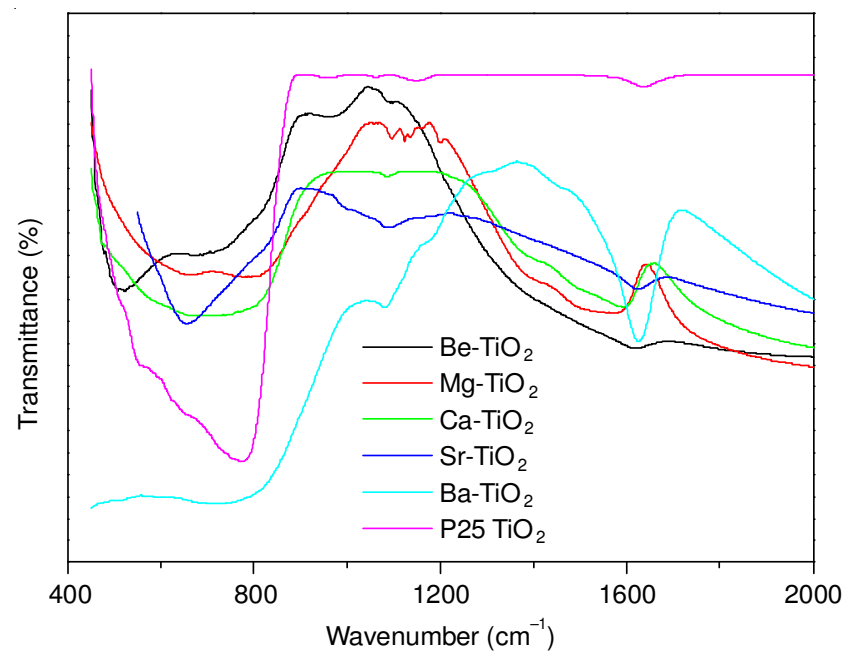

Fig. 5. IR spectra of the samples

Photoeletrochemical characterization of $\mathrm{Me}_{\mathrm{IIA}}-\mathrm{TiO}_{2}$ : Fig. 6 shows the SPS plots of pure $\mathrm{TiO}_{2}$ and $\mathrm{Me}_{\mathrm{IIA}}-\mathrm{TiO}_{2}$ with applied potential bias of $+1.0 \mathrm{~V}$. Among all investigated samples, the surface photovoltage response of $\mathrm{Me}_{\mathrm{IIA}}-\mathrm{TiO}_{2}$ nanopowder are positively correlated to the UV absorption intensity, that is, the surface photovoltage follow the order of $\mathrm{Ca}^{-\mathrm{TiO}_{2}}(0.0945 \mathrm{mV})>\mathrm{Sr}^{-\mathrm{TiO}_{2}}(0.0772 \mathrm{mV})>\mathrm{Ba}-\mathrm{TiO}_{2}$ $(0.0325 \mathrm{mV})>\mathrm{Mg}-\mathrm{TiO}_{2}(0.0184 \mathrm{mV})>\mathrm{Be}^{-\mathrm{TiO}_{2}}(0.0132 \mathrm{mV})$ $>\mathrm{TiO}_{2}(0.0077 \mathrm{mV})$. Comparatively, the surface photovoltage of $\mathrm{Ca}-\mathrm{TiO}_{2}$ is 12 times higher than that of pure $\mathrm{TiO}_{2}$ under the

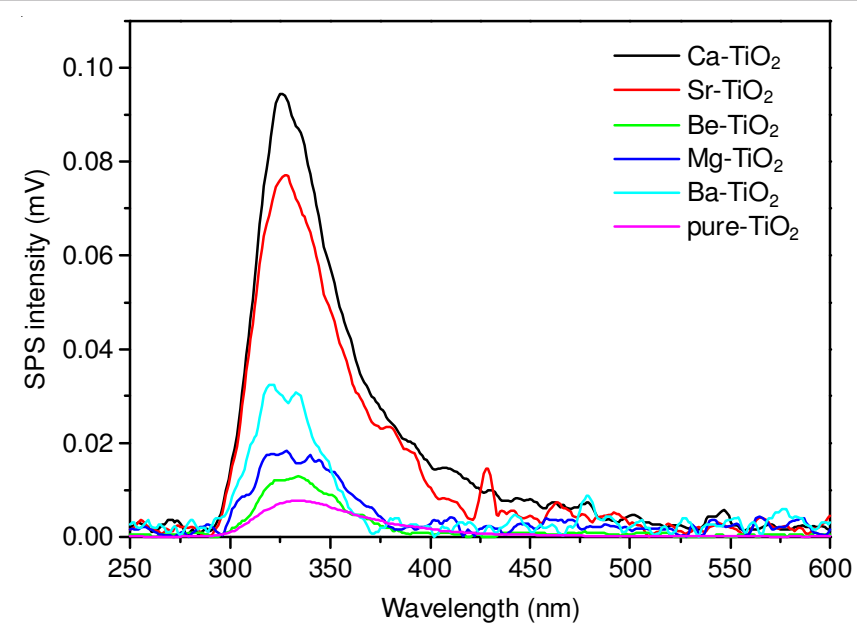

Fig. 6. Electrical field induced surface photovoltage spectrum in $\mathrm{Me}_{\mathrm{IIA}}{ }^{-}$ $\mathrm{TiO}_{2}$ nanomaterials

same condition, suggesting doped $\mathrm{TiO}_{2}$ have higher efficiency to transport the photo-generated electrons than pure $\mathrm{TiO}_{2}{ }^{18}$. The surface photovoltage response of $\mathrm{Me}_{\mathrm{IIA}}-\mathrm{TiO}_{2}$ appears at 300-420 nm, which belongs to the electronic band-band transition $\left(\mathrm{O}_{2 \mathrm{p}} \rightarrow \mathrm{Ti}_{3 \mathrm{~d}}\right)$ of $\mathrm{TiO}_{2}{ }^{19}$. Additionally, a weak peak at $420-$ $600 \mathrm{~nm}$ can also be observed, attributing to that the doping of $\mathrm{Me}_{\text {IIA }}$ narrows the band gap and leads to the excitation of defect to produce built-in electric field in $\mathrm{Me}_{\mathrm{IIA}}-\mathrm{TiO}_{2}$ space charge region, which reduce the separation efficiency of photogenerated electron-hole pairs ${ }^{20}$. Simultaneously, Dember effect also has a contribution to the weak photovoltage response. Nevertheless, the various crystallinity and particle size of $\mathrm{Me}_{\mathrm{IIA}}-\mathrm{TiO}_{2}$ nanopowder lead to a low Schottky barrier and built-in electric field created on the grain boundary. The concentration of photogenerated charges at the interface is low under weak illumination, resulting in that the photogenerated charges cannot cross the junction interface barrier. As known from the XRD results, it is found that the doping of $\mathrm{TiO}_{2}$ with $\mathrm{Me}_{\text {IIA }}$ reduces $\mathrm{TiO}_{2}$ crystallinity, inferring the existence of a large amount of surfaces states ${ }^{21}$. The surface state could change the configuration of nanoparticle's surface atoms, electron spin and electron spectrum and it may induce the appearance of non chemical equilibrium and non-integer coordination valence. Based on EFISPS principle, the surface state is sensitive toward the external electric field, whereas intrinsic band-band development is insensitive. The development of surface state is forbidden without the external electric field. Nevertheless, applying an external electric field enhances the transition probability of surface state to generate surface photovoltage response signals in the long wavelength ${ }^{22}$.

Photocatalytic degradation of fenvalerate: As shown in above mentioned results, the doped $\mathrm{TiO}_{2}$ possessed high photoconversion efficiency under visible-light irradiation, suggesting they might have remarkable visible-light-induced photocatalytic activity. The photocatalytic degradation of fenvalerate was used to evaluate the visible light activity of $\mathrm{Me}_{\mathrm{IIA}}-\mathrm{TiO}_{2}$. Fig. 7 shows the adsorption and photocatalytic degradation curves of fenvalerate $(50 \mathrm{mg} / \mathrm{L})$ by pure $\mathrm{TiO}_{2}$ and $\mathrm{Me}_{\mathrm{IIA}}-\mathrm{TiO}_{2}$. The adsorption equilibrium experiments were first conducted before the lamp was switched on. $\mathrm{Me}_{\mathrm{IIA}}-\mathrm{TiO}_{2}$ show different adsorption capacity due to the different surface states 


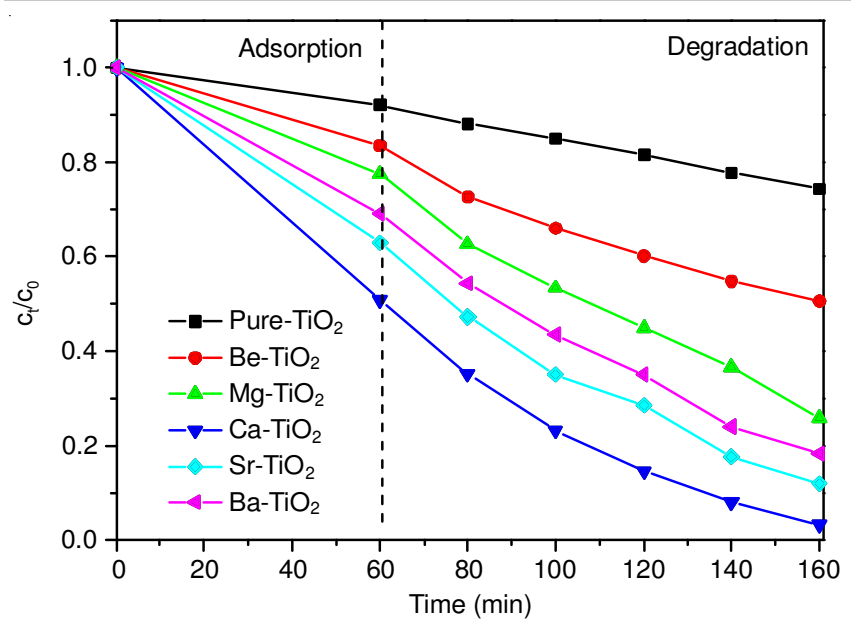

Fig. 7. Absorption and photodegradation of the fenvalerate

and SPS responses for different $\mathrm{Me}_{\mathrm{IIA}}$ and it follows an order of $\mathrm{TiO}_{2}<\mathrm{Be}-\mathrm{TiO}_{2}<\mathrm{Mg}-\mathrm{TiO}_{2}<\mathrm{Ba}-\mathrm{TiO}_{2}<\mathrm{Sr}-\mathrm{TiO}_{2}<\mathrm{Ca}-\mathrm{TiO}_{2}$. For pure $\mathrm{TiO}_{2}$, about $25.7 \%$ degradation efficiency was achieved after $100 \mathrm{~min}$ irradiation. As expected, the doped $\mathrm{TiO}_{2}$ exhibits high photocatalytic activity, after $100 \mathrm{~min}$ of visible light irradiation, 49.4, 74.2, 96.8, 88.1 and $81.7 \%$ of degradation efficiencies of fenvalerate can be obtained using Be-TiO $, \mathrm{Mg}_{2}-\mathrm{TiO}_{2}, \mathrm{Ca}-\mathrm{TiO}_{2}, \mathrm{Sr}-\mathrm{TiO}_{2}$ and $\mathrm{Ba}-\mathrm{TiO}_{2}$, respectively, implying that $\mathrm{Ca}-\mathrm{TiO}_{2}$ could produce more photogenerated charges and possesses higher photocatalytic degradation activity. It is coincided with the results obtained from the SPS response signals. The stronger of the SPS response signals intensities of the samples, the higher of the photocatalytic activity $^{22}$. As a consequence, it can be concluded that the quantum efficiency of $\mathrm{Me}_{\mathrm{IIA}}-\mathrm{TiO}_{2}$ follows an order of $\mathrm{Ca}-\mathrm{TiO}_{2}$ $>\mathrm{Ba}-\mathrm{TiO}_{2}>\mathrm{Mg}-\mathrm{TiO}_{2}>\mathrm{Sr}-\mathrm{TiO}_{2}>\mathrm{Be}-\mathrm{TiO}_{2}>\mathrm{TiO}_{2}$.

\section{Conclusion}

In the present study, a series of visible-light-driven photocatalysts of $\mathrm{Me}_{\mathrm{IIA}}-\mathrm{TiO}_{2}$ with enhanced visible light photocatalytic activity were successfully fabricated via a facile solid-state reaction approach with SDS as the template. Anatase was the main phase for all samples. The photocatalysts were comprised of spherical nanoparticles, the size distributions of nanoparticles are gradually widened with the increase of ionic radius and the decrease of charge density, the mass fraction of $\mathrm{Me}_{\text {IIA }}$ doped in the materials gradually increases. The BET surface areas of $\mathrm{TiO}_{2}$ doped with $\mathrm{Me}_{\text {IIA }}$ increased with a decrease in charge density and increase in charge size ratio of ions. The absorption edge of $\mathrm{Me}_{\mathrm{IIA}}-\mathrm{TiO}_{2}$ exhibited a remarkable red-shift as the $\mathrm{Me}_{\text {IIA }}$ was successfully embedded into the framework or the interstitial positions of $\mathrm{TiO}_{2}$ lattice. The adsorption capacity of $\mathrm{Me}_{\mathrm{IIA}}-\mathrm{TiO}_{2}$ followed an order of $\mathrm{TiO}_{2}<$
Be- $\mathrm{TiO}_{2}<\mathrm{Mg}-\mathrm{TiO}_{2}<\mathrm{Ba}-\mathrm{TiO}_{2}<\mathrm{Sr}-\mathrm{TiO}_{2}<\mathrm{Ca}-\mathrm{TiO}_{2}$. After 100 min of visible light irradiation, 49.4, 74.2, 96.8, 88.1 and $81.7 \%$ of degradation efficiencies of fenvalerate could be achieved using $\mathrm{Be}-\mathrm{TiO}_{2}, \mathrm{Mg}-\mathrm{TiO}_{2}, \mathrm{Ca}-\mathrm{TiO}_{2}, \mathrm{Sr}-\mathrm{TiO}_{2}$ and $\mathrm{Ba}-\mathrm{TiO}_{2}$, respectively, which was coincided with the results obtained from the SPS response signals. $\mathrm{Ca}-\mathrm{TiO}_{2}$ possessed the highest photocatalytic activity under visible-light irradiation and quantum efficiency.

\section{ACKNOWLEDGEMENTS}

This project was supported by the National Natural Science Foundation of China (No. 41271332), the Education Quality Promotion Foundation of Department of education, Guizhou Province, China (No. [2011]278-01), Guizhou Province Characteristic Leading Academic Discipline Project in Material Physics and Chemistry (No.[2011]208), Characteristic Key Laboratory Construction Fund of Guizhou Province (No.[ 2012]225) and Science and Technology Innovation Talent Team Foundation of Guizhou Province, China (No. [2013]4029).

\section{REFERENCES}

1. T. Micha, Catal. Today, 151, 58 (2000).

2. B. Soraa, K. Wannes and M.B Ana, Appl. Organomet. Chem., 692, 24 (2010).

3. A.B. Mohammad, A. Bahare and M. Nasser, Photochem. Photobiol., 1308, 87 (2011).

4. U.G. Akpan and B.H. Hameed J. Colloid Interf. Sci., 168, 357 (2011).

5. M.H. Mangrola, B.H. Parmar, A.S. Pillai and V.G. Joshi, Adv. Mater. Res., 488-489, 202 (2012).

6. Y.J. Choi, Z. Seeley and A. Bandyopadhyay, Sens Actuators B, 111, 124 (2007).

7. L.X. Deng, Y.L. Chen. M.Y. Yao, S.R. Wang, B.L. Zhu, W.P. Huang and S.M. Zhang, J. Sol-Gel Sci. Technol., 535, 53 (2010).

8. S.Y. Liu and Q.G. Feng, Adv. Mater. Res., 1462, 217 (2011).

9. S.Y. Liu, Q.L. Tang and Q.G. Feng, Appl. Surf. Sci., 5544, 257 (2011).

10. S.Y. Liu, G.C. Liu and Q.G. Feng, J. Porous Mater., 197, 17 (2010).

11. Y.L. Gao, S.Y. Liu and F. Zhang, Key Eng. Mater, 65, 509 (2012).

12. S.Y. Liu, F. Zhang and C.Y. Luo, Adv. Mater. Res., 1602, 652 (2013).

13. M.R. Hoffman, S.T. Martin and W. Choi, Chem. Rev., 69, 95 (1995).

14. R.C. Evans, An Introduction to Crystal Chemistry, Cambridge Univ. Press, Cambridge, edn. 2, p. 20 (1964).

15. D.T. Gen, L.L. Long and Q.Z. Zhang, Applied Geochemistry, Central South University Press, Changsha, Ch. 3 (2012).

16. S.Y. Liu, L.D. Wu and Z.X Zhao, J. Inorg. Mater, 902, 24 (2009).

17. X.B. Chen and S.S. Mao, Chem. Rev., 2891, 107 (2007).

18. L.Q. Jing, Z.H. Sun and F.L Yuan, China Sci. B: Chem., 53, 36 (2006) in Chinese.

19. L. Kronik and Y. Shapira, Surf. Sci. Rep., 1, 37 (1999).

20. T.F. Xie, D.J Wang and L.J. Zhu, J. Phys. Chem. B, 8177, 104 (2000).

21. L.Q. Jing, D.J. Wang and B.F. Xin, Acta Chim. Sin., 1008, 63 (2005).

22. Y.Q. Xue, Doctoral Dissertation, Effect of Particle Size on Phase Transformation and the Reaction Speed of Nano-System, Taiyuan University of Technology, Taiyuan (2005) (in Chinese). 